\title{
GENETIC, ENVIRONMENTAL EFFECTS AND STORAGE PERIOD IN ONION SEEDS QUALITY
}

\author{
EFEITOS GENÉTICOS, AMBIENTAIS E PERÍODO DE ARMAZENAMENTO NA \\ QUALIDADE DE SEMENTES DE CEBOLA
}

\begin{abstract}
Gabriel Mascarenhas MACIEL ${ }^{1}$; Fábio Janoni CARVALHO²; Marco Aurélio Rocha FERNANDES ${ }^{3}$; Igor Forigo BELOTI ${ }^{4}$; Camila Soares de OLIVEIRA ${ }^{3}$

1. Engenheiro Agrônomo, Professor, Doutor, Instituto de Ciências Agrárias - ICIAG, Universidade Federal de Uberlândia - UFU, Monte Carmelo, MG, Brasil. gabrielmaciel@ @iciag.ufu.br; 2. Engenheiro Agrônomo, Mestre, Instituto de Ciências Agrárias - ICIAG, Universidade Federal de Uberlândia - UFU, Monte Carmelo, MG, Brasil; 3. Graduando em Agronomia, Instituto de Ciências Agrárias ICIAG, Universidade Federal de Uberlândia - UFU, Monte Carmelo, MG, Brasil; 4. Engenheiro Agrônomo,Técnico de Laboratório, Mestre, Instituto de Ciências Agrárias - ICIAG, Universidade Federal de Uberlândia - UFU, Monte Carmelo, MG, Brasil.
\end{abstract}

\begin{abstract}
In several species, seed longevity may be influenced by genotype and storage environment. It is scarce researches that evaluated those effects in onion seeds. From the exposed, it was aimed to evaluate the behavior from onion seeds of different genotypes stored in three conditions of relative humidity $(25 ; 35$ and $45 \% \mathrm{RH})$ monitored during six different storage periods. The research was executed at the Laboratório de Análise de Sementes e Recursos Genéticos from Universidade Federal de Uberlândia, Monte Carmelo Campus -MG. After harvested, the seeds of two cultivars were storaged in three conditions (SC): 25,35 e $45 \%$ of relative humidity $(\mathrm{RH})$. It was kept the same temperature $\left(17^{\circ} \mathrm{C}\right)$ in all storage conditions. After one year of storage, it was collected monthly seed samples of each genotype inside each storage condition for evaluation of physiological potential with vigor and germination tests. There was significant effect in germination and vigor of the seeds in the storage period and condition and in genotype versus environment, in all analysed variables. The quality of onion seeds may be influenced by genotype, storage conditions and storage period. The best condition to storage onion seeds is at $35 \%$ of RH. Seed deterioration was increased with storage period, although, short storage periods have increased germination rates.
\end{abstract}

KEYWORDS: Allium cepa. Physiological quality. Deterioration.

\section{INTRODUCTION}

The onion (Allium cepa L.) represents the third vegetable in economic importance in Brazil and world. In 2014, onion yields in Brazil was nearly 1.65 million of tons in 57.7 thousands of hectares harvested (IBGE, 2015). Only brazilian market of onion seeds moved around 20 million US dollars, occurring sowing in more than 41,000 hectares (ABCSEM, 2012). Furthermore, due the proven potential related to heterosis exploration in onion hybrids (MALUF, 2001; MAY et al., 2007), united to the capacity to support high plant density, the demand of seeds has increase, not only in volume, but also in quality. The success of onion production is dependent of good seedling establishment in the field, as well as for other vegetables. Seed quality is defined by the sum of genetic, physical, physiological and sanitary attributes, and they can affect directly on the final stand establishment of an onion field. There are reports that onion seeds and may be influenced by genetic constitution and environmental conditions before sowing (RAO et al.,2006).

Relative humidity $(\mathrm{RH})$ can influence the physiological seed quality, especially the vigor, during the storage period. This influence is explained because of the relation between $\mathrm{RH}$ and seed moisture content, which can interfere in the control of metabolic events during the storage period. Although the best conditions for maintaining orthodox seed quality are low relative humidity and low temperature (NASCIMENTO et al., 2006), there is not a specific agreement for onion seeds $(A$. сера).

Storage period can also affect physiological seed quality (CUNHA et al., 2009). Medeiros et al. (2013) concluded that, for this variable, reduction of vigor is caused by lipid peroxidation during storage period. This deterioration is also affected by seed moisture content. Also, genotype is the basis of seed quality and frequently vigor's tests are used as selection criterion in breeding programs (MARCOS FILHO, 1999). For Gondim et al. (2006), genotype factor must be considered when quality of seed lots from different cultivars are evaluated.

Due the lack of researches allied to increasing demand for seeds with the best quality for onion production, it is necessary studies that relate possible effects of relative humidity, storage period and genotype with physiological seed quality of onion seeds. In this context, the purpose of this 
study was to evaluate the behavior from onion seeds of different genotypes stored in three conditions of relative humidity $(25 ; 35$ and $45 \% \mathrm{RH})$ monitored during the storage period.

\section{MATERIAL AND METHODS}

Laboratorial tests (standard germination test, germination speed index, first-count germination and germination at low temperature) were made at Laboratório de Análise de Sementes e Recursos Genéticos (LAGEN) of Universidade Federal de Uberlândia, Monte Carmelo CampusMG. Field tests (emergence speed index and seedling emergence) were developed in greenhouse at Estação Experimental de Hortaliças da UFU, Monte Carmelo Campus (altitude $873 \mathrm{~m}$, $18^{\circ} 42^{\prime} 43,19^{\prime \prime} \mathrm{S}$ and $47^{\circ} 29^{\prime} 55,8^{\prime \prime} \mathrm{W}$, humid temperate climate, with hot summers and dry winters).

It was used basic seeds of onion from the genotypes 'Sprint' and 'Mulata', harvested in July of 2012 in the city of Bagé/RS. After harvested, the seeds of each cultivar were divided in three equal portions and stored separately for one year $(07 / 15 / 12$ to $07 / 15 / 13)$, in the storage conditions (SC): 25,35 e $45 \%$ of relative humidity (RH). It was kept the same temperature $\left(17^{\circ} \mathrm{C}\right)$ in all storage conditions.

After a year of storage, it was collected monthly seed samples of each genotype inside each storage condition for evaluation of physiological potential with the following tests: moisture content (MC), electrical conductivity (EC), standard germination test (SGT), germination speed index (GSI), first-count germination (FCG), emergence speed index (ESI) seedling emergence (SE) and germination at low temperature (GLT).

In each collect performed monthly, it was checked moisture content of each genotype by oven method $105 \pm 3^{\circ} \mathrm{C}$ (BRASIL, 2009). For electrical conductivity (EC) it was performed the mass method (VIEIRA; KRZYZANOWSKI, 1999), using four subsamples of 50 seeds preweighed in precision balance $(0.0001 \mathrm{~g})$. After that, the seeds were placed in disposable plastic cups with $50 \mathrm{ml}$ of distilled water (electrical conductivity between 1 and $3 \mu \mathrm{S} . \mathrm{cm}^{-1}$ ), and remained in a Germinator Biochemical Oxygen Demand type (B.O.D.) set in constant temperature of $25^{\circ} \mathrm{C}$ for 24 hours. Past 24 hours, it was read electrical conductivity of solution with a conductivimeter, and the results were expressed by $\mu \mathrm{S} . \mathrm{cm}^{-1} \cdot \mathrm{g}^{-1}$ of seed.

Standard germination test (SGT) was made with four subsamples of 100 seeds distributed equally over two germitest paper sheets, moistened
2.5 times the weight of the substrate with distilled water, in gerbox and kept in Mangelsdorf Germinator at $25^{\circ} \mathrm{C}$ and 12 hours of photoperiod. Daily counts were performed to determine the germination speed index (GSI), being the $12^{\text {th }}$ day after sowing computed the germination percentage (BRASIL, 2009). It was used the formula proposed by Maguire (1962) to calculate GSI, where GSI = $\left(G_{l} / N_{l}\right)+\left(G_{2} / N_{2}\right)+\ldots+(G n / N n)$; being GSI: germination speed index; $G_{l}, G_{2}, \ldots, G n$ : number of germinated seeds in first, second, to the last count; and $N_{l}, N_{2}, \ldots, N n$ : number of days from sowing to the first, second and last count. It was also registered the first-count germination (FCG) of the germination percentages in the sixth day after sowing (NAKAGAWA, 1999).

It was adopted methodology recommended by AOSA (1983) and described by Dias and Alvarenga (1999) to measure Germination at Low Temperature (GLT), using four subsamples of 50 seeds each, uniformly distributed in transparent gerboxes with germitest paper previously moistened 2.5 times the weight of the substrate with distilled water. The water was kept at $15^{\circ} \mathrm{C}$ for 24 hours, before beginning of the test, so that seeds could have started the soaking process in the recommended temperature $\left(15^{\circ} \mathrm{C}\right)$. After sowing, the gerboxes were sealed with scotch tape and kept in B.O.D. incubator at $15{ }^{\circ} \mathrm{C}$ for seven days. After this time, gerboxes were unsealed and transferred to a Mangelsdorf Germinator regulated at $25^{\circ} \mathrm{C}$ for more seven days, with irrigation when necessary. The results were expressed as normal seedlings percentage with length higher or equal to $2.0 \mathrm{~cm}$.

Field tests were performed along with laboratorial tests. It was used four subsamples of 50 seeds to measure Emergence Speed Index (ESI). The seeds were distributed in individual cells of polystyrene trays filled with coconut fiber base commercial substrate. After sowing, trays were put at greenhouse and irrigated when necessary. The evaluations were daily, in a period of 13 days counted after sowing, computing the number of normal seedlings emerged each day. To calculate ESI, it was used the formula proposed by Maguire (1962): $E S I=E 1 / N 1+E 2 / N 2+\ldots+E n / N n$; where $E S I$ : emergence speed index; $E_{1}, E_{2}, \ldots, E n$ : number of germinated seedlings in first, second, to the last count; e $N_{l}, N_{2}, \ldots, N n$ : number of days from sowing to the first, second and last count. Seedling emergence (SE) was also made in conjoint with ESI test, computing the number of normal seedlings emerged at $13^{\text {th }}$ day after sowing, and the results were expressed as normal seedlings percentage (NAKAGAWA, 1999). 
The individual experiments were made following a complete randomized design, with four replications, in 2 x 3 factorial (Genotype x Storage condition). It was proceeded a conjoint analysis of the experiments with storage period stratification (because the experiments were independent and performed with same methodology), with the objective of evaluate if storage period affect the analyzed variables, making a $2 \times 3 \times 6$ triple factorial, with six different storage periods assumed after the installation of the first experiment $(0,30$, $60,90,120,150$ days). Conjoint analysis was available because the ratio between the highest and lowest residual mean square of each variable was lower than seven (BANZATO; KRONKA, 2006). Before conjoint analysis, the assumptions of normality of residuals and homogeneity of variances were performed for the individual experiments by Shapiro-Wilk and Levene tests, respectively. Statistical proceedings were executed with software SISVAR (FERREIRA, 2011) and the data were submitted to F-test $(p$-value $=0.01)$. If significant difference between treatments were detected, pairwise comparisons were performed by Tukey post hoc test ( $p$-value $=0.05$ ) for storage condition and genotype, and regression analysis were submitted for storage period. Only interactions of interest were performed with the aim of find trends between variables.

\section{RESULTS AND DISCUSSION}

Table 1. Average humidity degree (\%) for onion seeds of two genotypes (Sprint and Mulata) submitted to different storage conditions ( $25 \%, 35 \%$ and $45 \%$ of $\mathrm{RH}$ ) in their storage periods (SP).

\begin{tabular}{|c|c|c|c|}
\hline \multirow{2}{*}{$\begin{array}{l}\text { SP (days after } 1^{\text {st }} \\
\text { experiment) }\end{array}$} & \multirow{2}{*}{ Storage condition $(\% \mathrm{RH})$} & \multicolumn{2}{|c|}{ Genotypes } \\
\hline & & Sprint & Mulata \\
\hline \multirow{3}{*}{0} & 25 & $5,50 \mathrm{Ab}$ & $5,14 \mathrm{Ab}$ \\
\hline & 35 & $5,72 \mathrm{Ab}$ & $5,50 \mathrm{Ab}$ \\
\hline & 45 & $8,25 \mathrm{Aa}$ & $7,34 \mathrm{Ba}$ \\
\hline \multirow{3}{*}{30} & 25 & $5,54 \mathrm{Ab}$ & $5,15 \mathrm{Ab}$ \\
\hline & 35 & $5,70 \mathrm{Ab}$ & $5,45 \mathrm{Ab}$ \\
\hline & 45 & $8,21 \mathrm{Aa}$ & $7,32 \mathrm{Ba}$ \\
\hline \multirow{3}{*}{60} & 25 & $5,50 \mathrm{Ab}$ & $5,12 \mathrm{Ab}$ \\
\hline & 35 & $5,75 \mathrm{Ab}$ & $5,52 \mathrm{Ab}$ \\
\hline & 45 & $8,12 \mathrm{Aa}$ & $7,35 \mathrm{Aa}$ \\
\hline \multirow{3}{*}{90} & 25 & $5,58 \mathrm{Ab}$ & $5,15 \mathrm{Ab}$ \\
\hline & 35 & $5,70 \mathrm{Ab}$ & $5,54 \mathrm{Ab}$ \\
\hline & 45 & $8,29 \mathrm{Aa}$ & $7,30 \mathrm{Ba}$ \\
\hline \multirow{3}{*}{120} & 25 & $5,55 \mathrm{Ab}$ & $5,16 \mathrm{Ab}$ \\
\hline & 35 & $5,73 \mathrm{Ab}$ & $5,53 \mathrm{Ab}$ \\
\hline & 45 & 8,36 Aa & $7,26 \mathrm{Ba}$ \\
\hline \multirow{3}{*}{150} & 25 & $5,54 \mathrm{Ab}$ & $5,12 \mathrm{Ab}$ \\
\hline & 35 & $5,76 \mathrm{Ab}$ & $5,56 \mathrm{Ab}$ \\
\hline & 45 & $8,42 \mathrm{Aa}$ & $7,36 \mathrm{Ba}$ \\
\hline
\end{tabular}

Means, followed by the same small letters in columns, and capital letters in lines, do not differ significantly by Tukey's test ( $p$-value $\leq 0.05$ ).

Table 1 shows moisture content $(\%)$ of the onion seed lots stored at different periods and environmental conditions. In a general way, for the distinct lots of seeds evaluated, it was verified similar moisture content in two storage conditions (25 and 35\% RH), independent from the analyzed genotype. Uniformity between lots revealed that even in the storage condition of $25 \%$ as $35 \%$ of $\mathrm{RH}$, there is no significant interference of the seed hygroscopic equilibrium with the ambience. Seeds moisture content is influenced by relative humidity of the storage ambience, affecting their physiological quality (TORRES, 2005). Metabolic activity of seeds can be reduced with water content maintenance, preserving physiological quality and increasing storage period (CARDOSO et al., 2012). However, significant effects (Tukey post hoc test) proportionated to the seed lots when storaged at $45 \%$ of $\mathrm{RH}$, indicate that seeds suffered from the hygroscopic equilibrium in this conditions. Results of Neto et al. (2014) showed that moisture content of pumpkin seeds were directly affected by relative humidity. In this context, when seeds moisture content are higher, their physiological quality tends to be less due deterioration increase, causing higher respiration rate. Martins et al. (2014) found this described behavior in carrot seeds.

The results from $\mathrm{F}$ test $(p$-value $<0.01)$ reveal significant effect in germination and vigor in storage period and condition, and also in Genotype versus environment interaction in all analyzed variables (EC, SGT, GSI, FCG, ESI, SE, GLT) (Table 2). 
Table 2. Mean square from conjoint analysis of storage period (0,30, 60, 90, 120 and 150 days) in three storage conditions (25, 35 and $45 \%$ of RH) and two genotypes (Sprint and Mulata).

\begin{tabular}{|c|c|c|c|c|c|c|c|}
\hline \multirow{2}{*}{ Source } & $\mathrm{EC}$ & SGT & GSI & FCG & ESI & SE & GLT \\
\hline & \multicolumn{7}{|c|}{ Mean square } \\
\hline Storage period (SP) & $7595.59^{* *}$ & $516.69^{* *}$ & $4331.33^{* *}$ & $4713.26^{* * *}$ & $1541.64^{* *}$ & $9771.11^{* *}$ & $220.31^{* *}$ \\
\hline Genotype $(\mathrm{G})$ & $201.74^{\mathrm{ns}}$ & $1475.84^{* *}$ & $5000.97^{* *}$ & $1936.00^{* *}$ & $25.88^{\mathrm{ns}}$ & $215.11^{\mathrm{ns}}$ & $560.11^{* *}$ \\
\hline Storage condition (SC) & $29476.67^{* *}$ & $808.05^{* *}$ & $207.85^{* *}$ & $142.02^{* *}$ & $991.42^{* *}$ & $4801.77^{* *}$ & $2482.19^{* *}$ \\
\hline $\mathrm{SP} * \mathrm{G}$ & $1984.14^{* *}$ & $23.99^{\mathrm{ns}}$ & $15.72^{\mathrm{ns}}$ & $7.45^{\mathrm{ns}}$ & $132.18^{* *}$ & $325.77^{* *}$ & $83.77^{\mathrm{ns}}$ \\
\hline $\mathrm{SP} * \mathrm{SC}$ & $893.35^{* *}$ & $10.948^{\mathrm{ns}}$ & $35.56^{\mathrm{ns}}$ & $28.22^{\mathrm{ns}}$ & $64.56^{* *}$ & $257.17^{* *}$ & $9.29^{\mathrm{ns}}$ \\
\hline $\mathrm{G}^{*} \mathrm{SC}$ & $11113.55^{\text {** }}$ & $1299.25^{* *}$ & $4767.3^{* *}$ & $3532.58^{* *}$ & $515.51^{* *}$ & $2237.44^{* *}$ & $2109.52^{* *}$ \\
\hline $\mathrm{SP}^{*} \mathrm{G}^{*} \mathrm{SC}$ & $665.49^{\mathrm{ns}}$ & $19.36^{\mathrm{ns}}$ & $64.41^{\mathrm{ns}}$ & $44.93^{\mathrm{ns}}$ & $32.27^{\mathrm{ns}}$ & $170.71^{* *}$ & $52.09^{\mathrm{ns}}$ \\
\hline Error & $245.57^{\mathrm{ns}}$ & $14.99^{\mathrm{ns}}$ & $25.5^{\mathrm{ns}}$ & $22.57^{\mathrm{ns}}$ & $11.34^{\mathrm{ns}}$ & $72.16^{\mathrm{ns}}$ & $41.8^{\mathrm{ns}}$ \\
\hline $\mathrm{CV}(\%)$ & 7.17 & 4.42 & 5.5 & 6.53 & 11.3 & 15.25 & 7.61 \\
\hline
\end{tabular}

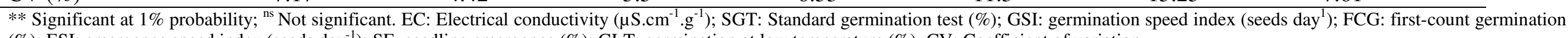
(\%); ESI: emergence speed index (seeds day ${ }^{-1}$ ); SE: seedling emergence (\%); GLT: germination at low temperature (\%); CV: Coefficient of variation. 
Germination data at Table 3 showed difference in germination in function of genotype and storage conditions. According to Lima et al. (2007), genetic factor affects directly on physiological seed quality. The best storage condition for the seeds of cultivar Mulata was at $25 \%$ of $\mathrm{RH}$ providing $96 \%$ of germination, contradicting with cultivar Sprint that displayed better germination $(91.87 \%)$ in storage condition of $35 \% \mathrm{RH}$, during the storage period.

Differences between the lots indicated alterations in seed deterioration, occurring variability in lots of same cultivar (Table 3 ). Results from EC, SGT, GSI, FCG, ESI, SE and GLT tests supports superior germination from Sprint genotype at $35 \%$ of RH. Superior quality in Mulata seeds was found in storage at $25 \%$ of $\mathrm{RH}$ reflecting best results in all vigor tests, including EC $\left(197.49 \mu \mathrm{S} . \mathrm{cm}^{-1} \cdot \mathrm{g}^{-1}\right)$, indicating less deterioration in this condition. Many factors can affect the electrical conductivity in seeds (RODRIGUES et al., 2006), including the genotype (VIEIRA et al., 2002), as verified by Silva et al. (2010) in cultivars of soybean. The results are in concordance with Silva et al. (2011) and Martins et al. (2014), who reported interference of genotype factors in vigor of carrot seeds.

Table 3. Mean variation of different storage conditions (SC) $(25 \%, 35 \%$ and $45 \%$ of RH) in each genotype (Mulata and Sprint) for the analyzed variables.

\begin{tabular}{lccccccc}
\hline \multirow{2}{*}{$\begin{array}{c}\text { SC } \\
(\% \mathrm{RH})\end{array}$} & EC & SGT & \multicolumn{1}{c}{ GSI } & FCG & ESI & SE & GLT \\
\cline { 2 - 8 } & & \multicolumn{7}{c}{ Mulata } \\
\hline 25 & $197.49 \mathrm{~b}$ & $96.00 \mathrm{a}$ & $107.37 \mathrm{a}$ & $83.83 \mathrm{a}$ & $32.89 \mathrm{a}$ & $63.91 \mathrm{a}$ & $94.08 \mathrm{a}$ \\
35 & $200.05 \mathrm{~b}$ & $92.42 \mathrm{~b}$ & $91.68 \mathrm{~b}$ & $70.00 \mathrm{c}$ & $31.71 \mathrm{a}$ & $60.67 \mathrm{a}$ & $92.25 \mathrm{a}$ \\
45 & $262.04 \mathrm{a}$ & $84.21 \mathrm{c}$ & $94.31 \mathrm{~b}$ & $75.50 \mathrm{~b}$ & $26.09 \mathrm{~b}$ & $46.25 \mathrm{~b}$ & $74.50 \mathrm{~b}$ \\
\cline { 2 - 8 } & & \multicolumn{7}{c}{ Sprint } \\
35 & $226.43 \mathrm{a}$ & $77.58 \mathrm{c}$ & $73.64 \mathrm{~b}$ & $57.75 \mathrm{c}$ & $25.58 \mathrm{~b}$ & $47.08 \mathrm{~b}$ & $65.50 \mathrm{~b}$ \\
45 & $195.84 \mathrm{~b}$ & $91.87 \mathrm{a}$ & $96.46 \mathrm{a}$ & $77.58 \mathrm{a}$ & $37.50 \mathrm{a}$ & $71.00 \mathrm{a}$ & $82.00 \mathrm{a}$ \\
& $230.20 \mathrm{a}$ & $83.95 \mathrm{~b}$ & $96.89 \mathrm{a}$ & $72.00 \mathrm{~b}$ & $25.06 \mathrm{a}$ & $45.41 \mathrm{~b}$ & $76.50 \mathrm{a}$ \\
\hline
\end{tabular}

Means followed by the same small letters in columns, do not differ significantly by Tukey's test ( $p$-value $\leq 0.05)$. EC: Electrical conductivity $\left(\mu \mathrm{S} . \mathrm{cm}^{-1} \cdot \mathrm{g}^{-1}\right)$; SGT: Standard germination test $(\%)$; GSI: germination speed index (seeds day ${ }^{-1}$ ); FCG: first-count germination (\%); ESI: emergence speed index (seeds day ${ }^{-1}$ ); SE: seedling emergence (\%); GLT: germination at low temperature $(\%)$.

This work reveals that RH could be capable of reduce or maximize onion seeds longevity, occurring specific conditions according to genotype (Table 3). Studies by Binotti et al. (2008) demonstrated that storage of bean seeds in higher relative humidities associated with higher temperatures intensifies deterioration because of respiration rate rise. Germination was affected by relative humidity during storage period in pumpkin seeds (NETO et al., 2014).

Germination superiority in each analysed genotype in the beginning of storage is not guarantee of quality keeping until the moment of sowing or longevity similar to other lots with same initial germination. In this context, at ending of storage period, it could be different final quality of the lots. Vegetables in general, are more inclined to deterioration, because of lesser seed reserves compared to other field crops (FREITAS, 2009).

The storage period affected all the variables analysed, despite that interaction between genotype and storage condition only occurred to EC, ESI and SE. A quadratic increase was observed for SGT, GSI, FCG, and GLT (Figure 1). These results showed how seed deterioration increases and germination rates lower with time. However, it was observed increment of values with short time storage (maximum data obtained around sixty days in the four equations).

This could be explained by reactive oxygen (ROS) and nitrogen (RNS) species increasing regardless of storage conditions. Both molecules are formed in seeds at stress situations, but small concentrations of them helps to accelerate and active metabolic pathways on seeds, improving germination (KRANNER et al., 2010). Until sixty days, ROS and RNS increase helped the germination, but after this period, the continuous increase affected seeds and their deterioration.

Electrical conductivity values confirm linear seed deterioration with time in all storage conditions (Figure 2). However $35 \%$ of $\mathrm{RH}$ condition performed the best results with the lowest increases of EC. For ESI and SE, no regression was significantly adjusted. Evaluating watermelon seeds behavior stored for twelve months, Torres (2005) obtained increased values in electrical conductivity from the eighth month, due to deterioration process. 
Same results were obtained by Nakada et al. (2010) with cucumber seeds.
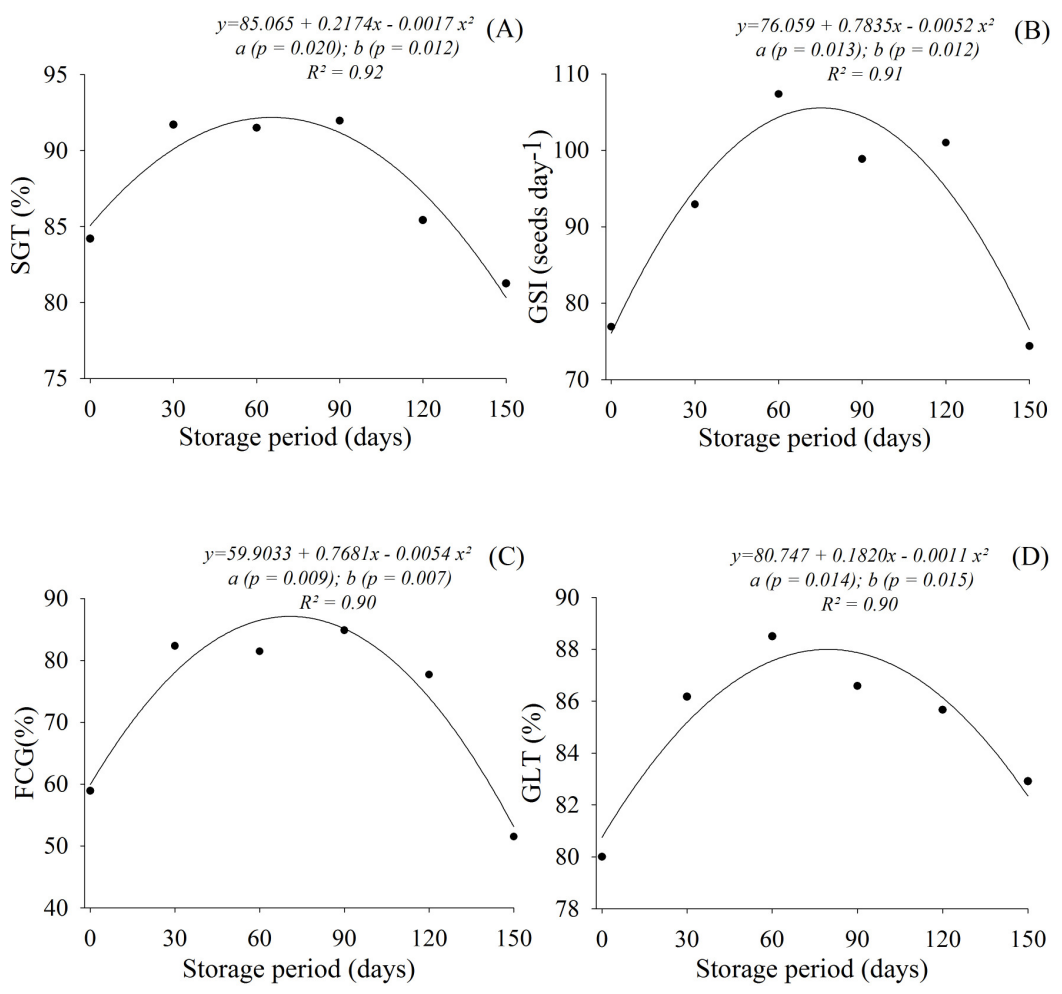

Figure 1. Standard germination test (SGT) (A); germination speed index (GSI) (B); first-count germination (FCG) (C); and germination at low temperature (GLT) (D) variation on different storage periods.
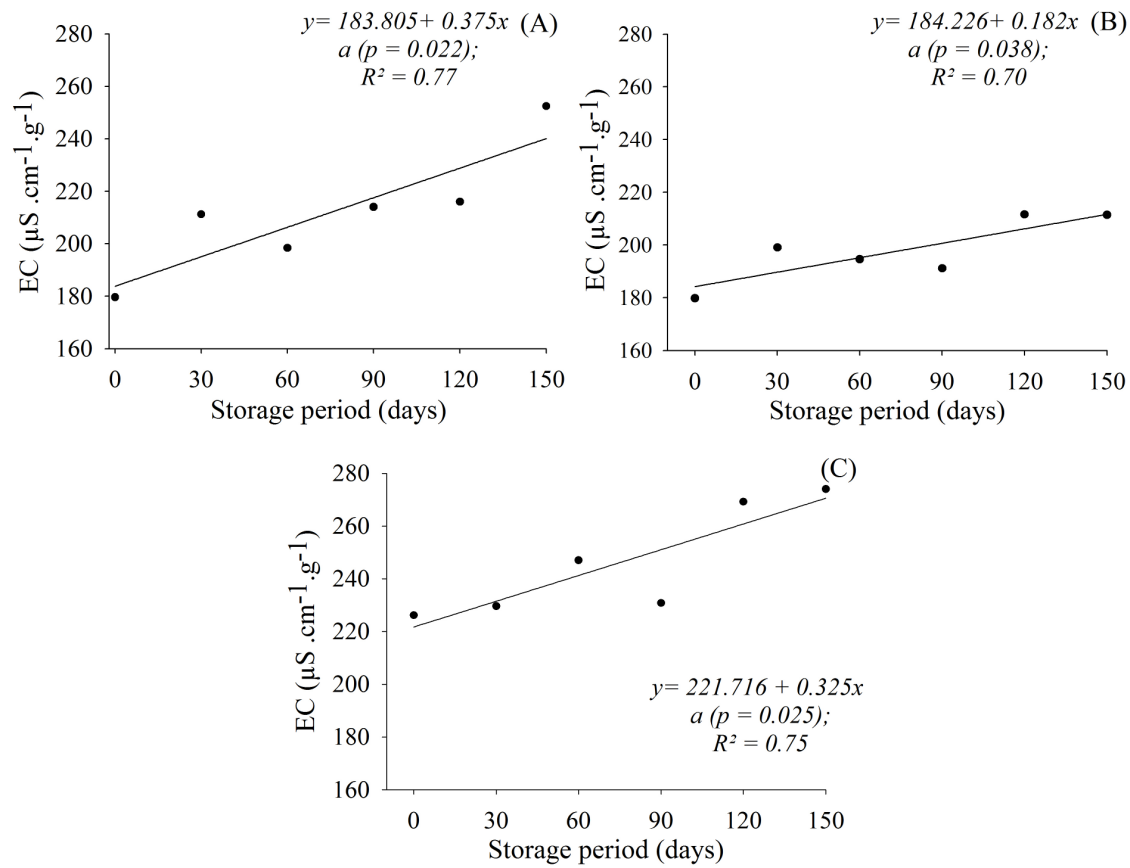

Figure 2. Effect of storage period at storage conditions of 25 (A), 35 (B) and 45\% (C) of relative humidity for electrical conductivity of onion seeds. 
In a general way, storage at $35 \%$ of $\mathrm{RH}$ resulted at lower deterioration rates in onion seeds. Between the two analysed genotypes (Mulata and Sprint) the best condition varied (25 and 35\% RH, respectively), indicating that not only between lots, but also between genotypes, there is reduction in seed deterioration speed in function of different storage conditions. For pumpkin seeds, results of Neto et al. (2014), differed from those found, where the best storage condition was at $45 \%$ of $\mathrm{RH}$. Appropriate conditions of storage enable physiological seed quality maintenance, minimizing their deterioration (CARDOSO et al., 2012).

\section{CONCLUSIONS}

The quality of onion seeds may be influenced by genotype, storage conditions and storage period.

The best condition to storage onion seeds is at $35 \%$ of $\mathrm{RH}$.

Seed deterioration was increased with storage period, although, short storage periods have increased germination rates.

RESUMO: Em várias espécies, a longevidade das sementes pode ser influenciada pelo genótipo e ambiente de armazenamento. São escassas pesquisas que avaliaram tais efeitos em sementes de cebola. Diante do exposto, objetivouse avaliar a qualidade fisiológica das sementes de diferentes genótipos de cebola armazenados em três condições de umidade relativa $(25 ; 35$ e $45 \%$ UR) durante seis períodos de armazenamento. A pesquisa foi desenvolvida no Laboratório de Análise de Sementes e Recursos Genéticos da Universidade Federal de Uberlândia, Campus Monte Carmelo-MG. Após colhidas, as sementes de dois genótipos foram armazenadas em três condições de armazenamento $(25,35$ e $45 \%$ de umidade relativa) em temperatura padrão $\left(17^{\circ} \mathrm{C}\right)$ durante o período de um ano. Em seguida coletou-se mensalmente amostras de sementes representando cada genótipo em função das condições propostas de armazenamento para avaliação do potencial fisiológico por meio de testes de vigor e percentagem de germinação. Pode-se constar o efeito significativo tanto na germinação quanto no vigor das sementes no período e ambiente de armazenamento e na interação entre genótipo versus ambiente, em todas as variáveis analisadas. A qualidade das sementes de cebola pode ser influenciada pelo genótipo e pelas condições e período de armazenamento. A melhor condição de armazenamento para sementes de cebola foi de $35 \%$ UR. A deterioração da semente aumentou com o período de armazenamento, embora que pequenos períodos de armazenamento melhoraram as taxas de germinação.

PALAVRAS-CHAVE: Allium cepa. Qualidade fisiológica. Deterioração.

\title{
REFERENCES
}

\author{
ABCSEM - ASSOCIAÇÃO BRASILEIRA DO COMÉRCIO DE SEMENTES E MUDAS. Pesquisa de \\ mercado. 2012. Available in: http://www.abcsem.com.br Accessed on: 05 sep. 2014.
}

AOSA - ASSOCIATION OF OFFICIAL SEED ANALYSTS. Seed vigor testing handbook, East Lansing, 1983. 88 p. (Contribution 32).

BANZATO, D. A.; KRONKA, S. N. (Eds.). Experimentação agrícola. Jaboticabal: Funep, 237p. 2006.

BINOTTI, F. F. S.; HAGA, K. I.; CARDOSO, E. D.; ALVES, C. Z.; SÁ, M. E.; ARF, O. Efeito do período de envelhecimento acelerado no teste de condutividade elétrica e na qualidade fisiológica de sementes de feijão. Acta Scientiarum Agronomy, Maringá, v. 30, n. 2, p. 247-254, 2008.

http://dx.doi.org/10.4025/actasciagron.v30i2.1736

BRASIL. Ministério da Agricultura e da Reforma Agrária. Regras para análise de sementes. Brasília: SNDA/DNDV/CLAV, 392p, 2009.

http://www.agricultura.gov.br/images/MAPA/arquivos_portal/ACS/sementes_web.pdf.

CARDOSO, R. B.; BINOTTI, F. F. S.; CARDOSO, E. D. Potencial fisiológico de sementes de crambe em função de embalagens e armazenamento. Pesquisa Agropecuária Tropical, Goiânia, v. 42, n. 3, p. 272-278, 2012. http://dx.doi.org/10.1590/S1983-40632012000300006 
CUNHA, J. P. A. R.; OLIVEIRA, P.; SANTOS, C. M.; MION, R. L. Qualidade das sementes de soja após a colheita com dois tipos de colhedora e dois períodos de armazenamento. Ciência Rural, Santa Maria, v. 39, n. 5, p. 1420-1425, 2009. http://dx.doi.org/10.1590/S0103-84782009005000063

DIAS, D. C. F. S.; ALVARENGA, E. M. Teste de germinação a baixa temperatura. In: KRZYZANOWSKI, F. C.; VIEIRA, R. D.; FRANÇA NETO, J. B. (Eds.). Vigor de sementes: conceitos e testes. Londrina: ABRATES, p. 7.1-7.3. 1999.

FERREIRA, D.F. Sisvar: a computer statistical analysis system. Ciência e Agrotecnologia, Lavras, v. 35, n. 6, p. 1039-1042, 2011.

FREITAS, R. A. Deterioração e armazenamento de sementes de hortaliças. In: NASCIMENTO, W. M. (Ed.). Tecnologia de sementes de hortaliças. Brasília: Embrapa Hortaliças, p.155-184. 2009.

GONDIM, T. C. O.; ROCHA, V. S.; SANTOS, M. M.; MIRANDA, G. V. Avaliação da qualidade fisiológica de sementes de milho-crioulo sob estresse causado por baixo nível de nitrogênio. Revista Ceres, Viçosa, v. 53, n. 307, p. 413-417, 2006.

IBGE - INSTITUTO BRASILEIRO DE GEOGRAFIA E ESTATÍSTICA. Levantamento sistemático da produção agrícola 2015. Available at:

ftp://ftp.ibge.gov.br/Producao_Agricola/Levantamento_Sistematico_da_Producao_Agricola_[mensal]/Fascicul o/lspa_201502.pdf . Accessed on: 24 mar. 2015.

KRANNER, I.; MINIBAYEVA, F.V; BECKETT, R.P.; SEAL, C.E. What is stress? Concepts, definitions and application in seed science. New Phytologist, v.188, p.655-673, 2010. http://dx.doi.org/10.1111/j.1469-

8137.2010.03461.x

LIMA, W. A. A.; BORÉM, A.; DIAS, D. C. F. S.; MOREIRA, M. A.; DIAS, L. A. S.; PIOVESAN, N. D. Retardamento de colheita como método de diferenciação de genótipos de soja para qualidade de sementes. Revista Brasileira de Sementes, Londrina, v. 29, n. 1, p. 186-192, 2007. http://dx.doi.org/10.1590/S010131222007000100026

MAGUIRE, J. D. Speeds of germination-aid selection and evaluation for seedling emergence and vigor. Crop Science, v. 2, p. 176-177, 1962.

MALUF, W. R. Heterose e emprego de híbridos $F_{1}$ em hortaliças. In: NASS, L. L.; VALOIS, A. C. C.; MELO, I. S.; VALADARES-INGLIS, M. C. (Eds.). Recursos genéticos e melhoramento-plantas. Rondonópolis: Fundação MT, p. 327-356, 2001.

MARCOS FILHO, J. Testes de vigor: importância e utilização. In: KRZYZANOWSKI, F.C.; VIEIRA, R.D.; FRANÇA NETO, J.B. (Eds.). Vigor de sementes: conceitos e testes. Londrina: ABRATES, p. 1-21. 1999.

MARTINS, C. C.; SILVA, N.; MACHADO, C. G. Testes para a seleção de populações de cenoura visando ao vigor e à longevidade das sementes. Ciência Rural, Santa Maria, v. 44, n. 5, p. 768-774, 2014. http://dx.doi.org/10.1590/S0103-84782014005000001

MAY, A.; CECÍLIO FILHO, A. B.; PORTO, D. R. Q.; VARGAS, P. F.; BARBOSA, J. C. Produtividade de híbridos de cebola em função da população de plantas e da fertilização nitrogenada e potássica. Horticultura Brasileira, Brasília, v. 25, n. 1, p. 53-59, 2007. http://dx.doi.org/10.1590/S0102-05362007000100011

NASCIMENTO, W. M.; PEREIRA, R. S.; FREITAS, R. A.; BLUMER, L.; MUNIZ, M. F. B. Colheita e armazenamento de sementes de coentro. Pesquisa Agropecuária Brasileira, Brasília, v. 41, n. 12, p. 17931801, 2006. http://dx.doi.org/10.1590/S0100-204X2006001200015 
MEDEIROS, L. T.; SALES, J. F.; SOUZA, R. G.; ALVES, B. A.; FREITAS, N. F. Qualidade fisiológica de sementes de amendoim forrageiro submetidas a diferentes tempos e ambientes de armazenamento. Revista Brasileira Saúde e Produção Animal, Salvador, v. 14, n. 3, p. 427-477, 2013. http://dx.doi.org/10.1590/s1519-99402013000300006

NAKADA, P. G.; OLIVEIRA, J. A.; MELO, L. C.; SILVA, A. A.; SILVA, P. A.; PERINA. F. J. Desempenho durante o armazenamento de sementes de pepino submetidas a diferentes métodos de secagem. Revista Brasileira de Sementes. Londrina, v. 32, n. 3, p. 42-51, 2010.

NAKAGAWA, J. Testes de vigor baseados no desempenho de plântulas. In: KRZYZANOWSKI, F. C.; VIEIRA, R. D.; FRANÇA NETO, J. B. (Eds.). Vigor de sementes: conceitos e testes. Londrina: ABRATES, p. 2.1-2.24. 1999.

NETO, A. F.; DANTAS, B. F.; ALMEIDA, F. A. C.; LIMA, M. S.; SILVA, F. F. S. Influência da embalagem e do local de armazenamento na qualidade fisiológica de sementes de abóbora "jacarezinho" (Curcubita moschata Duch). Engenharia na Agricultura, Viçosa, v. 22, n. 4, p. 294-305, 2014.

RAO, R. G. S.; SINGH, P. M.; MATHURA, R. Storability of onion seeds and effects of packaging and storage conditions on viability and vigour. Scientia Horticulturae, v. 11, p. 1-6, 2006.

http://dx.doi.org/10.1016/j.scienta.2006.06.002

RODRIGUES, M. B. C.; VILLELA, F. A.; TILlMANN, M. A. A.; CARVALHO, R. Pré-hidratação em sementes de soja e eficiência do teste de condutividade elétrica. Revista Brasileira de Sementes, Pelotas, v. 28, n. 2, p. 168-181, 2006. http://dx.doi.org/10.1590/S0101-31222006000200023

SILVA, G.O.; VIEIRA, J. V.; NASCIMENTO, W. M.; BOITEUX, L. S. Estratégias de seleção para germinação de sementes de cenoura em condições de temperaturas elevadas. Revista Ceres, Viçosa, v. 58, n. 1, p. 121-125, 2011.

SILVA, J. B.; LAZARINI, E.; SÁ, M. E. Comportamento de sementes de cultivares de soja submetidos a diferentes períodos de envelhecimento acelerado. Bioscience Journal, Uberlândia, v. 26, n. 5, p. 755-762, 2010.

TORRES, S. B. Qualidade de sementes de melancia armazenadas em diferentes embalagens e ambientes. Revista Ciência Agronômica, v. 36, n. 2, p. 163-168, 2005.

VIEIRA, R. D.; KRZYZANOWSKI, F. C. Teste de condutividade elétrica. In: KRZYZANOWSKI, F.C.; VIEIRA, R.D.; FRANÇA NETO, J.B. (Eds.). Vigor de sementes: conceitos e testes. Londrina: ABRATES, p. 1-26, 1999.

VIEIRA, R. D.; PENARIO, A. L.; PERECIN, D.; PANOBIANCO, M. Condutividade elétrica e teor de água inicial das sementes de soja. Pesquisa Agropecuária Brasileira, Brasília, v. 37, n. 9, p. 1333-1338, 2002. http://dx.doi.org/10.1590/S0100-204X2002000900018 